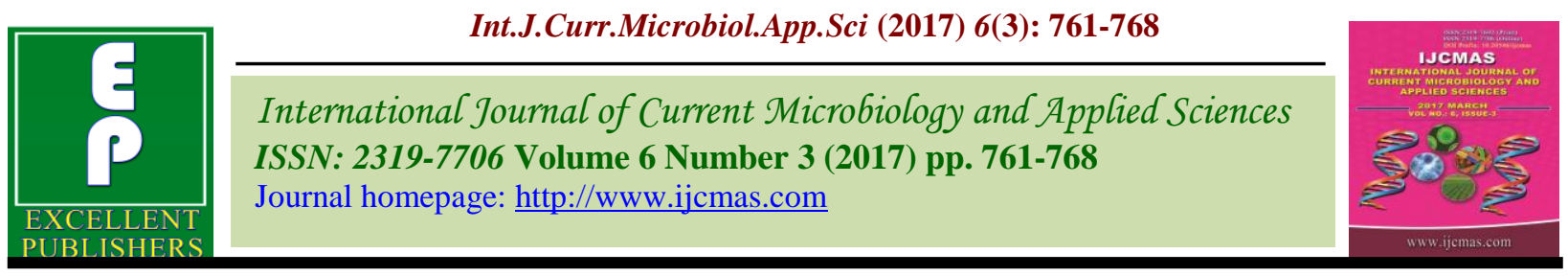

Original Research Article

https://doi.org/10.20546/ijcmas.2017.603.088

\title{
A New Method Development and Validation for Identification and Quantification of Methoxyfenozide Insecticide Residues in Grapes using High Performance Liquid Chromatography
}

\author{
S.N.V.S. Murthy ${ }^{1}$, Tentu Nageswara Rao $^{2} *$, Prathipati Revathi ${ }^{2}$ and S. Seshamma \\ ${ }^{1}$ Department of Organic Chemistry, D.L.R. P.G. College, Gollalamamidada, AP, India \\ ${ }^{2}$ Department of Chemistry, Krishna University, Machilipatnam, AP India \\ ${ }^{3}$ Department of Bio Chemistry, AN University, Guntur, AP, India \\ *Corresponding author
}

\begin{tabular}{|c|c|}
\hline & A B S T R A C T \\
\hline Keywords & \multirow{4}{*}{$\begin{array}{l}\text { A simple and inexpensive method was developed using liquid - liquid extraction, } \\
\text { together with high performance chromatographic method for determination of } \\
\text { methoxyfenozide residues in grapes. The evaluated parameters include the extracts } \\
\text { by distilled water and acetonitrile solvents. The method was validated using } \\
\text { grapes samples spiked with methoxyfenozide at different fortification levels ( } 0.05 \text {, } \\
0.1 \text { and } 0.5 \mu \mathrm{g} / \mathrm{g} \text { ). Average recoveries (using each concentration three replicates) } \\
\text { ranged } 86-95 \% \text {, with relative standard deviations less than } 5 \% \text {, calibration } \\
\text { solutions concentration in the range } 0.05-5.0 \mu \mathrm{g} / \mathrm{mL} \text { and limit of detection (LOD) } \\
\text { and limit of quantification (LOQ) were } 0.02 \mu \mathrm{g} / \mathrm{g} \text { and } 0.05 \mu \mathrm{g} / \mathrm{g} \text { respectively. } \\
\text { Finally the grapes residue samples were analyzed by HPLC. }\end{array}$} \\
\hline $\begin{array}{l}\text { HPLC, } \\
\text { methoxyfenozide, } \\
\text { Grapes, LOD and } \\
\text { LOQ. }\end{array}$ & \\
\hline Article Info & \\
\hline $\begin{array}{l}\text { Accepted: } \\
\text { 15 February } 2017 \\
\text { Available Online: } \\
10 \text { March } 2017\end{array}$ & \\
\hline
\end{tabular}

\section{Introduction}

Methoxyfenozide

[3-methoxy-2methylbenzoicacid 2-(3, 5- dimethylbenzoyl)2-(1, 1-dimethyl-ethyl) hydrazide; RH-2485] is a diacylhydrazine insecticide that was first introduced by Rohm and Haas Company in 1996 (Le et al., 1996). Le presented INTREPID as an efficacious member of the diacylhydrazine class. Methoxyfenozide acts as an agonist or mimic of the insect molting hormone, 20-hydroxyecdysone (20E) (Smagghe et al., 1999; Dhadialla et al., 1998; Carlson et al., 2001). The nature of the insecticide is to mimic the hormone and bind to the sites so that precocious molting occurs (Dhadialla et al., 1999; Nakagawa et al., 2000).
Methoxyfenozide acts against a wide range of lepidopteron pests of cotton, corn, and other major agronomic crops (Oberlander et al., 2000). Methoxyfenozide has been shown to be more effective than tebufenozide on armyworms, Spodoptera sp and other pests (Smagghe et al., 2000). Methoxyfenozide is an effective agent for control of codling moth Cydia pomonella (Smagghe et al., 1998), Southwestern corn borer, Distraea grandiosella, European corn borer Ostrinia nubilalis, rice stem borers and cotton leaf worm. Ecdysteroid agonists can have an effect on fecundity and fertility in leaf rollers, with methoxyfenozide being the most potent. Methoxyfenozide can be very effective when 
interacting with other compounds such as juvenile hormone mimic (Trisyono et al., 2000).

\section{Experimental}

\section{Standards, reagents and samples}

The analytical standard of methoxyfenozide (99.6\%) was obtained from Sigma Aldrich. HPLC grade acetonitrile and water was purchased from Rankem and grapes were purchased from local market.

\section{Standard stock solutions}

The methoxyfenozide stock solutions was individually prepared in acetonitrile at a concentration level $500 \mu \mathrm{g} / \mathrm{g}$ and stored in a freezer at $-18^{\circ} \mathrm{C}$. The stock standard solutions were used for up to 3 months. Suitable concentrations of working standards were prepared from the stock solutions by dilution using acetonitrile, immediately prior to sample preparation.

\section{Sample preparation}

Representative 500.0 gram portions of grapes fortified with $0.5 \mathrm{~mL}$ of working standard stock solution. The sample was allowed to stand at room temperature for one hour, before it was kept at refrigerator condition, until analysis.

\section{Extraction procedure of grapes}

The representative $50 \mathrm{~g}$ of grapes homogenized sample was taken in a $500 \mathrm{ml}$ stoppered conical flask. To this added $100 \mathrm{ml}$ acetonitrile, water (90:10) and extracted using an end-over end mechanical shaker for about 30 minutes and filtered. Extraction was repeated with $50 \mathrm{ml}$ of same solvent. Combined the extract and dried over sodium sulphate. Reduced the volume using vacuum rotary evaporator made up to suitable volume with acetonitrile for HPLC analysis.

\section{HPLC-PDA separation parameters}

Instrument: Shimadzu High Performance Liquid Chromatograph system equipped with LC-20AT pump and SPD-20A PDA detector, SIL -20AC interfaced with LCsolution software system.

Column used: Agilent $\mathrm{C}_{18}$ column $(150 \mathrm{~mm} \mathrm{x}$ $4.6 \mathrm{~mm}$ i.d x $5 \mu \mathrm{m}$ particle size)

Column Oven: $30^{\circ} \mathrm{C}$

Temperature

Volume injected: $20 \mu \mathrm{l}$

Mobile phase A: Acetonitrile (55 v/v)

Mobile phase B: $0.1 \% \mathrm{H}_{3} \mathrm{PO}_{4}$ in water $(45 \mathrm{v} / \mathrm{v})$

Flow rate $(\mathrm{ml} / \mathrm{min}): \quad 1.0$

Wave length (nm): $254 \mathrm{~nm}$

Retention time:

(approximately)

Methoxyfenozide: 6.5 minutes

\section{Method validation}

Method validation ensures analysis credibility. In this study, the parameters accuracy, precision, linearity and limits of detection (LOD) and quantification (LOQ) were considered (Tentu Nageswara Rao et al., 2015; Karri Apparao et al., 2015). The accuracy of the method was determined by recovery tests, using samples spiked at concentration levels of $0.05,0.1$ and $0.5 \mu \mathrm{g} / \mathrm{g}$.

Linearity was determined by different known concentrations $(0.05,0.1,0.5,1.0,2.0$ and 5.0 $\mu \mathrm{g} / \mathrm{mL}$ ) were prepared by diluting the stock solution. The limit of detection (LOD $\mu \mathrm{g} / \mathrm{g}$ ) was determined as the lowest concentration giving a response of 3 times the baseline noise defined from the analysis of control (untreated) sample. The limit of quantification (LOQ $\mu \mathrm{g} / \mathrm{g}$ ) was determined as the lowest 
concentration of a given fungicide giving a response of 10 times the baseline noise.

\section{Results and Discussion}

\section{Specificity}

Aliquots of methoxyfenozide, control sample solution, extracted solvents and mobile phase solvents were assayed to check the specificity. There were no matrix peaks in the chromatograms to interfere with the analysis of residues shown in (Figure 1 and Figure 2). Furthermore, the retention time of methoxyfenozide was $6.5 \quad \mathrm{~min}$ (Approximately).

\section{Linearity}

$50.10 \mathrm{mg}$ of methoxyfenozide reference standard was taken into $50 \mathrm{~mL}$ volumetric flask and dissolved in HPLC water, sonicated and made up to the mark with the same solvent. The concentration of the stock solution was $1000 \mu \mathrm{g} / \mathrm{mL}$. From this stock solution prepared by different known concentrations of standard solutions $(0.05$, $0.1,0.5,1.0,2.0$ and $5.0 \mu \mathrm{g} / \mathrm{mL}$ ) were prepared into different $10 \mathrm{~mL}$ volumetric flasks and made upto the mark with acetonitrile. The serial dilution details were presented in table 1 . These standard solutions were directly injected into a HPLC.

A calibration curve has been plotted of concentration of the standards injected versus area observed and the linearity of method was evaluated by analyzing six solutions.

The peak areas obtained from different concentrations of standards were used to calculate linear regression equation. This was $\mathrm{Y}=8292.00 \mathrm{X}+0.121$ with correlation coefficient of 0.9999 respectively. A calibration curve showed in figure 3.

\section{Accuracy and precision}

Recovery studies were carried out at $0.05,0.1$ and $0.5 \mu \mathrm{g} / \mathrm{g}$ fortification levels for methoxyfenozide in grapes. The recovery data and relative standard deviation values obtained by this method are summarized in table 2 .

These numbers were calculated from four (3) replicate analyses of given sample (methoxyfenozide) made by a single analyst on one day. The repeatability of method satisfactory $(\mathrm{RSDs}<5 \%)$.

\section{Detection and quantification limits}

The limit of quantification was determined to be $0.05 \mu \mathrm{g} / \mathrm{g}$. The quantitative limit was defined as the lowest fortification level evaluated at which acceptable average recoveries $(87-96 \%, \quad \mathrm{RSD}<5 \%)$ were achieved. This quantitative limit also reflects the fortification level at which an analyte peak is consistently generated at approximately 10 times the baseline noise in the chromatogram. The limit of detection was determined to be $0.05 \mu \mathrm{g} / \mathrm{g}$ at a level of approximately three times the back ground of control injection around the retention time of the peak of interest.

\section{Storage stability}

A storage stability study was conducted at refrigerator condition $\left(5 \pm 3^{\circ} \mathrm{C}\right)$ and Ambient temperature $\left(25 \pm 5^{\circ} \mathrm{C}\right)$ of $0.5 \mu \mathrm{g} / \mathrm{g}$ level fortified fruit samples were stored for a period of 30 days at this temperature.

Analysed for the content of methoxyfenozide before storing and at the end of storage period. The percentage dissipation observed for the above storage period was only less than $3 \%$ for methoxyfenozide showing no significant loss of residues on storage. The results are presented in tables 3 and 4 . 
Table.1 Serial dilutions of linearity standard solutions

\begin{tabular}{|c|c|c|c|}
\hline $\begin{array}{c}\text { Stock solution } \\
\text { concentration } \\
(\boldsymbol{\mu g} / \mathbf{m L})\end{array}$ & $\begin{array}{c}\text { Volume taken } \\
\text { from stock } \\
\text { solution }(\mathbf{m L})\end{array}$ & $\begin{array}{c}\text { Final } \\
\text { make up } \\
\text { volume } \\
(\mathbf{m L})\end{array}$ & $\begin{array}{c}\text { Obtained } \\
\text { concentration } \\
(\boldsymbol{\mu g} / \mathbf{m L})\end{array}$ \\
\hline 1000 & 0.100 & 10 & 10.0 \\
\hline 10 & 5.00 & 10 & 5.0 \\
\hline 10 & 2.00 & 10 & 2.0 \\
\hline 10 & 1.00 & 10 & 1.0 \\
\hline 10 & 0.5 & 10 & 0.5 \\
\hline 10 & 0.1 & 10 & 0.1 \\
\hline 1.0 & 0.5 & 10 & 0.05 \\
\hline
\end{tabular}

Table.2 Recoveries of the methoxyfenozide from fortified grapes control sample $(n=3)$

\begin{tabular}{|c|c|c|}
\hline $\begin{array}{c}\text { Fortified } \\
\text { Concentration } \\
(\mathbf{m g} / \mathbf{k g})\end{array}$ & Replication & Recovery (\%) \\
\cline { 2 - 3 } & & Grapes \\
\hline \multirow{4}{*}{0.05} & $\mathbf{R} 1$ & 85.12 \\
\cline { 2 - 3 } & $\mathbf{R 2}$ & 86.52 \\
\cline { 2 - 3 } & $\mathbf{R 3}$ & 86.78 \\
\cline { 2 - 3 } & Mean \pm S.d. & $\mathbf{8 6 . 1 4} \pm \mathbf{0 . 8 9}$ \\
\hline \multirow{4}{*}{0.1} & $\mathbf{R 1}$ & 91.28 \\
\cline { 2 - 3 } & $\mathbf{R 2}$ & 90.54 \\
\cline { 2 - 3 } & $\mathbf{R 3}$ & 92.18 \\
\cline { 2 - 3 } & Mean \pm S.d. & $\mathbf{9 1 . 3 3} \pm \mathbf{0 . 8 2}$ \\
\hline \multirow{4}{*}{0.5} & $\mathbf{R 1}$ & 95.47 \\
\cline { 2 - 3 } & $\mathbf{R 2}$ & 95.71 \\
\cline { 2 - 3 } & $\mathbf{R 3}$ & 95.38 \\
\cline { 2 - 3 } & Mean \pm S.d. & $\mathbf{9 5 . 5 2} \pm \mathbf{0 . 1 7}$ \\
\hline
\end{tabular}

These numbers were calculated from four (3) replicate analyses of given sample (methoxyfenozide) made by a single analyst on one day. The repeatability of method satisfactory (RSDs $<5 \%$ ). 
Table.3 Storage stability Details at refrigerator condition $\left(5 \pm 3^{\circ} \mathrm{C}\right)$

\begin{tabular}{|c|c|c|}
\hline $\begin{array}{c}\text { Fortification } \\
\text { Concentration } \\
\text { in } \mu \mathrm{g} / \mathrm{g} \\
\end{array}$ & $\begin{array}{l}\text { Storage } \\
\text { Period in } \\
\text { Days } \\
\end{array}$ & Recovery in \% \\
\hline \multirow{18}{*}{0.5} & \multirow[t]{6}{*}{ 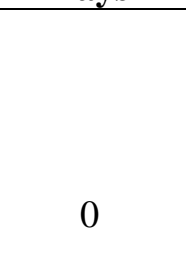 } & 97.45 \\
\hline & & 96.74 \\
\hline & & 96.89 \\
\hline & & 95.96 \\
\hline & & 97.05 \\
\hline & & 96.44 \\
\hline & \multirow{3}{*}{$\begin{array}{c}\text { Average } \\
\text { STDEV } \\
\text { RSD in \% } \\
\end{array}$} & 96.76 \\
\hline & & 0.51 \\
\hline & & 0.53 \\
\hline & \multirow{6}{*}{30} & 93.17 \\
\hline & & 92.71 \\
\hline & & 93.06 \\
\hline & & 92.85 \\
\hline & & 93.19 \\
\hline & & 93.89 \\
\hline & \multirow{3}{*}{$\begin{array}{c}\text { Average } \\
\text { STDEV } \\
\text { RSD in \% }\end{array}$} & 93.15 \\
\hline & & 0.41 \\
\hline & & 0.44 \\
\hline
\end{tabular}

Table.4 Storage stability details at ambient temperature $\left(25 \pm 2^{\circ} \mathrm{C}\right)$

\begin{tabular}{|c|c|c|}
\hline $\begin{array}{c}\text { Fortification } \\
\text { Concentration in } \\
\mu \mathrm{g} / \mathrm{g}\end{array}$ & $\begin{array}{l}\text { Storage } \\
\text { Period in } \\
\text { Days }\end{array}$ & Recovery in \% \\
\hline \multirow{18}{*}{ pods } & \multirow{6}{*}{ ( } & 92.89 \\
\hline & & 93.49 \\
\hline & & 93.26 \\
\hline & & 94.55 \\
\hline & & 93.26 \\
\hline & & 94.87 \\
\hline & \multirow{3}{*}{$\begin{array}{c}\text { Average } \\
\text { STDEV } \\
\text { RSD in \% } \\
\end{array}$} & 93.72 \\
\hline & & 0.80 \\
\hline & & 0.85 \\
\hline & \multirow{6}{*}{30} & 91.55 \\
\hline & & 90.69 \\
\hline & & 92.89 \\
\hline & & 92.13 \\
\hline & & 91.95 \\
\hline & & 90.88 \\
\hline & \multirow{3}{*}{$\begin{array}{c}\text { Average } \\
\text { STDEV } \\
\text { RSD in \% } \\
\end{array}$} & 91.68 \\
\hline & & 0.82 \\
\hline & & 0.90 \\
\hline
\end{tabular}


Fig.1 Representative chromatogram at grapes control

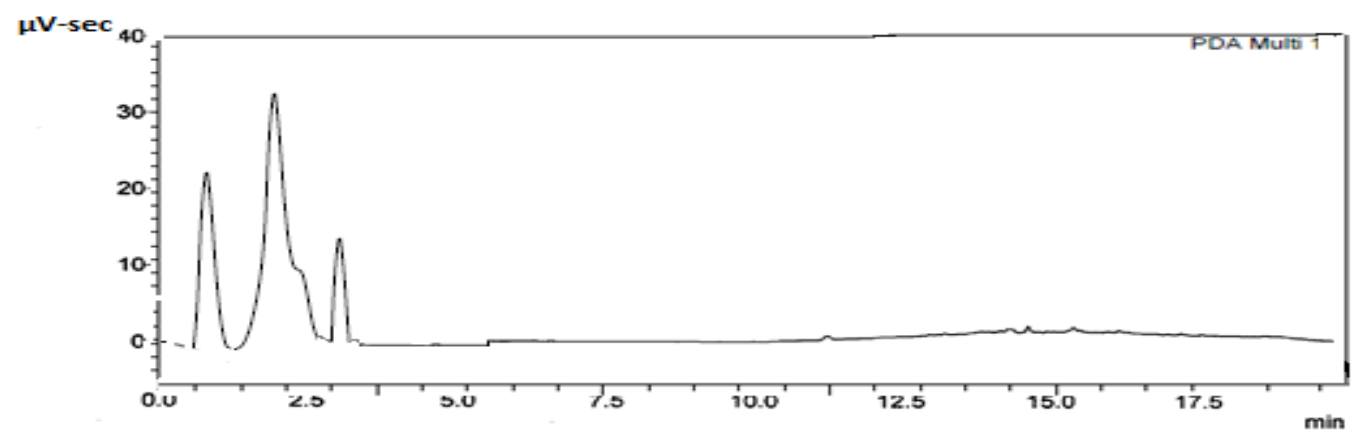

Fig.2 Representative chromatogram at fortification level of $0.05 \mu \mathrm{g} / \mathrm{g}$

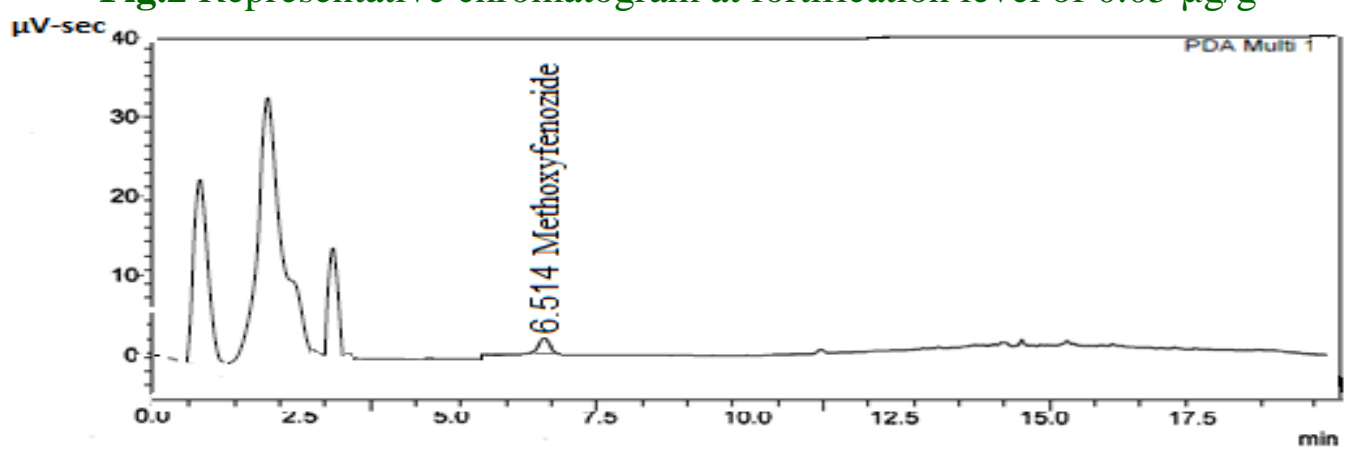

Fig.3 Representative calibration curve of methoxyfenozide

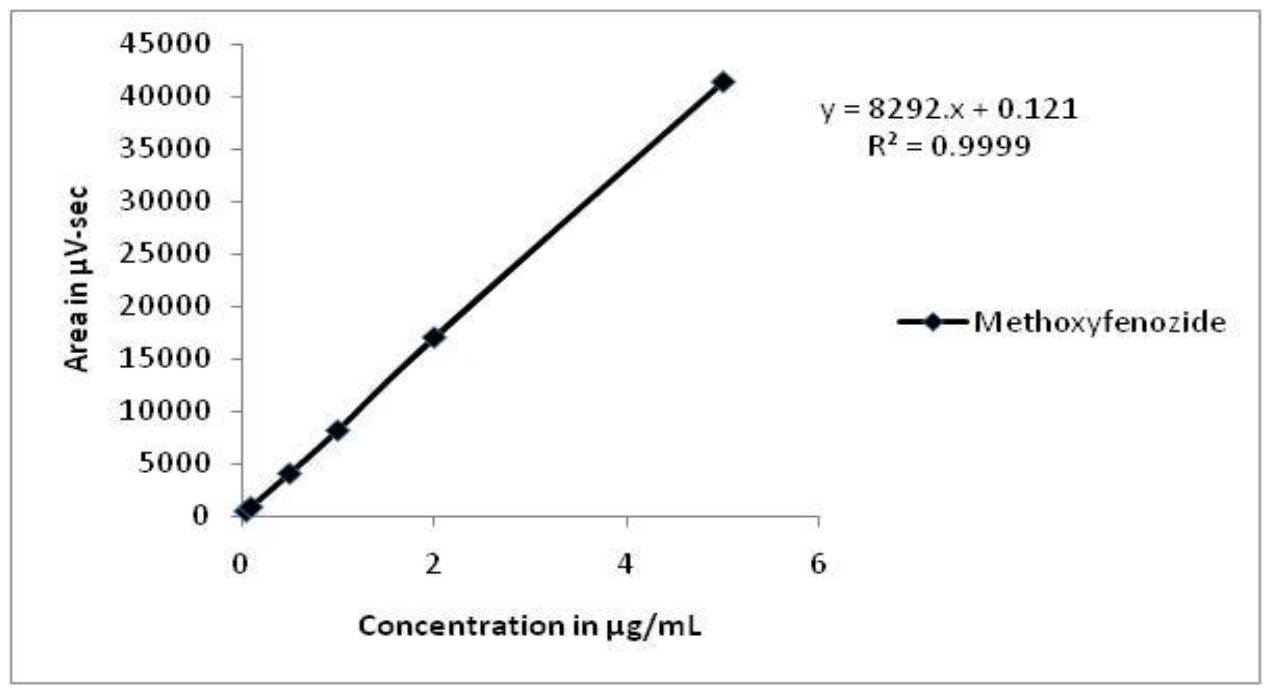

\section{Calculations}

The concentration of acetaminophen in the samples analyzed by HPLC was determined directly from the standard curve.

$\mathrm{Y}=\mathrm{mx}+\mathrm{c}$

Where,

$\mathrm{Y}=$ peak area of standard $\left(\mu \mathrm{V}^{*} \mathrm{sec}\right)$

$\mathrm{m}=$ the slope of the line from the calibration curve 
$\mathrm{x}=$ concentration of injected sample $(\mathrm{mg} / \mathrm{L})$

$c=' y$ ' intercept of the calibration curve

The recovered concentration or Dose concentration was calculated by using the formula:

Recovered concentration or Dose concentration $=\frac{(\mathrm{X}-\mathrm{c}) \mathrm{X} \mathrm{D} \times 100}{\mathrm{~m} \mathrm{X} \mathrm{P}}$

Where,

$\mathrm{m}=$ the slope of the line from the calibration curve

$\mathrm{x}=$ sample area of injected sample $\left(\mu \mathrm{V}^{*} \mathrm{sec}\right)$

$\mathrm{c}=$ ' $\mathrm{y}$ ' intercept of the calibration curve

$\mathrm{D}=$ Dilution Factor

$\mathrm{P}=$ Purity of Test item

$\%$ Recovery $=\frac{\text { Recovered Concentration }}{- \text { Fortified Concentration }} \times 100$

In conclusion, this paper describes a fast, simple sensitive analytical method based on HPLC-PDA to determine the methoxyfenozide residues in grapes. The LLE extraction procedure is very simple and inexpensive method for determination of methoxyfenozide residues in grapes. Satisfactory validation parameters such as linearity, recovery, precision and LOQ were established by following South African National Civic Organization (SANCO) guidelines. Therefore, the proposed analytical procedure could be useful for regular monitoring, residue labs and research scholars to determine the methoxyfenozide residues in different commodities (fruit, juice, seed, oil, and water and soil samples).

\section{Acknowledgement}

The authors are thankful to the Dr. Gowtham Prasad, S.V.V University, Hyderabad for his keen interest and help.

\section{References}

Carlson, G.R., Dhadialla, T.S., Hunter, R., Jansson, R.R., Jany, C.S., Lidert, Z.,
Slawecki, R.A. 2001. The chemical and biological properties of methoxyfenozide, a new insecticidal ecdysteroid agonist. Pest Manag. Sci., 57: 115-119.

Dhadialla, T.S., Carlson, G.R., Le, D.P. 1998. New insecticides with ecdysteroidal and juvenile hormone activity. Annu. $R e \mathrm{~V}$. Entomol., 43: 545-569.

Dhadialla, T.S., Jansson, R.K. 1999. Nonsteroidal ecdysone agonists: New tools for IPM and insect resistance management. Pestic. Sci., 55: 357-359.

Karri Apparao., Surendra Babu, M.S., Tentu Nageswara Rao., Basaveswara Rao, M.V. 2015. A novel method for determination of topramezone residues in maize. Oriental J. Chem., 31: 213218.

Le, D.P., Thirugnanam, M., Lidert, Z., Carlson, G.R., Ryan, J.B. 1996. A new selective insecticide for caterpillar control.Brighton Crop Prot. Conf Pests Dis., 481-486.

Nakagawa, Y., Minakuchi, C., Ueno, T. 2000. Inhibition of $[3 \mathrm{H}]-$ ponasterone $\mathrm{A}$ binding by ecdysone agonists in the intact Sf-9 cell line. Steriods, 65: 537- 
542.

Oberlander, H., Silhacek, D.L., Porcheron, P. 1995. Non-steroidal ecdysteroid agonists: Tools for the study of hormonal action. Arch. Insect Biochem. Physiol., 28: 209-223.

SANCO Guidelines. Method validation and quality control procedures for pesticide residues analysis in food and feed. Document NO. SANCO/10684/2009.

Smagghe, G., Carton, B., Heirman, A., Tirry, L. 2000. Toxicity of four dibenzoylhydrazine correlates with evagination-induction in the cotton leafworm. Pestic. Biochem. Physiol., 68: 49-58.

Smagghe, G., Carton, B., Wesemael, W., Ishaaya, I., Tirry, L. 1999. Ecdysone agonists Mechanism of action and application on Spodoptera species. Pestic. Sci., 55: 386-389.

Tentu Nageswara Rao, et al. 2015. Determination of Ethoxysulfuron Residues in Sugarcane Juice followed by HPLC-PDA Detection and Confirmation of Residues by LCMS/MS. Eurasian J. Anal. Chem., 10(3): 187-194.

Trisyono, A., Goodman, C.L., Grasela, J.J., Mcintosh, A.H., Chippendale, G.M. 2000. Establishment and characterization of an Ostrinia nubilalis cell line, and its response to ecdysone agonists. In Vitro Cell, Dev. Biol. Anim., 36: 400-404.

\section{How to cite this article:}

Murthy, S.N.V.S., Tentu Nageswara Rao, Prathipati Revathi and Seshamma, S. 2017. A New Method Development and Validation for Identification and Quantification of Methoxyfenozide Insecticide Residues in Grapes using High Performance Liquid Chromatography. Int.J.Curr.Microbiol.App.Sci. 6(3): 761-768. doi: https://doi.org/10.20546/ijcmas.2017.603.088 